\title{
EFFICACY OF A PLANT GROWTH REGULATOR IN THE CULTURE OF COFFEE
}

\author{
EFICÁCIA DE BIORREGULADOR NA CULTURA DO CAFÉ
}

\author{
Fernando Simoni BACILIERI'; Luara Cristina DE LIMA²; Regina Maria Quintão LANA³; \\ Dayane Salinas Nagib GUIMARÃES²; Marina Alves CLEMENTE ${ }^{1}$ \\ 1. Doctor's Degree in the Institute of Agricultural Sciences of the Federal University of Uberlandia, Brazil. \\ ferbacilieiri@zipmail.com.br; 2. Master's Degree in the Institute of Agricultural Sciences of the Federal University of Uberlandia, \\ Brazil; 3. Professor, Doctor, In Institute of Agricultural Sciences of the Federal University of Uberlandia, Brazil, Brazil.
}

\begin{abstract}
The purpose of this work was to evaluate the efficacy of a plant growth regulator applied at different growth stages in coffee. The experiment was conducted in the years 2010/2011 and 2011/2012 on the Docas 1 farm, using Mundo Novo IAC 379-19 coffee cultivar, with spacing 4 meter between rows and 0.8 meter between plants and 10 plants per plot. The experimental design was in blocks at random, with two factors and three repetitions. The first factor was the dose of the product ( 0.25 and 0.5 liter per hectare per application) and second factor was the time of applications according to the phenological stages (pre-flowering, post-flowering and pinhead). The control treatment (control) consisted of the absence of the application of the plant growth regulator. Biometric aspects (number of internodes and length of reproductive branches in centimeters, number of fruits on the fourth and fifth node on reproductive branches) and productivity were evaluated. Collected data were analyzed using Tukey test at 0.05 of significance. The application of a plant growth regulator at different growth stages of development of coffee leads to increased biometric variables in coffee: the number of internodes, the average number of fruits on the fourth and fifth node and the length of reproductive branches. The productivity of coffee can be increased with the use of plant growth regulators, particularly at the dose of 0.5 liter per hectare per application, regardless of the application period, promoting productivity up to $46.9 \%$. It is not possible to state that the presence of substances similar to phytohormones in plant growth regulators is responsible for the increase in productivity without making isolate application of these substances.
\end{abstract}

KEYWORDS: Coffea arabica L. Phytohormones. Fertilizer technologies.

\section{INTRODUCTION}

Coffee (Coffea arabica L.) is a major agricultural export from Brazil, thus the availability of technologies such as plant growth regulators are important, because may increase crop yield and improve the quality of the final drink.

The bioregulators intensify and improve the absorption of nutrients by plants (BINSFELD et al., 2014), making the use of these viable in the exploitation of the productive potential of crops (SILVA et al., 2012). These substances are natural or synthetic, from two or more plant growth regulators (cytokinins, gibberellins, auxins) mixed with other substances (amino acids, nutrients and vitamins) (SILVA et al, 2008), and act as activators of the metabolism of plant cells, strengthening the immune system and reactivating the physiological processes at different stages of development (SILVA et al., 2010).

At low doses, bioregulators favor the performance of vital processes of the plants, enabling them to obtain satisfactory yields in adverse environmental conditions. With different levels of mineral fertilizers, these are not capable of providing all the essential nutrients to meet the needs of the plant, but it increases the absorption of mineral plant, thus improving the efficiency of use of the nutrient both at the root, as in leaves (MUGNAI et al., 2008).

Albrecht et al. (2009) in cotton observed that the bioregulator increased the percentage of emergence of the seedlings and the speed of root growth, in addition to cause seedlings more vigorous. Avila et al. (2008), Fields et al. (2008), Klahold et al. (2006) showed that they affected germination and the biomass of dry weight of the seed and promoted the growth of plants in height.

Other studies showed that plant growth regulators may not favor or even decrease the absorption of nutrients by plants, indicating that the response to the applications depend on other factors such as plant species and the composition of humic substances in the products used for that purpose. More information is needed about the real effect of these products on plant development (FERREIRA et al., 2007).

There are few studies on the use of plant growth regulators in coffee; therefore, the aim of this study was to evaluate the effectiveness of a plant growth regulator applied at different growth stages in coffee. 


\section{MATERIAL AND METHODS}

The experiment was conducted in 2010/2011 and 2011/2012 agricultural years on the Docas 1farm located by the MG-223 highway, in the city of Araguari-MG, latitude 18 $38^{\prime} 56^{\prime \prime} \mathrm{S}$, longitude $48^{\circ} 11^{\prime} 13^{\prime \prime} \mathrm{W}$ and altitude of $940 \mathrm{~m}$.

The maintenance of humidity of soil water was obtained by means of a system of irrigation by dripping self compensation. Before beginning of the treatments, evaluations of the uniformity of the drip irrigation system were conducted by calculating the statistical uniformity coefficient, the emission uniformity coefficient and uniformity coefficient of absolute emission.
BACILIERI, F. S. et al.

An automatic weather station located in the city of Araguari by Procafe, Integrated Program of Support for Coffee Technology, provided data used to control the irrigation, which helped to estimate the evapotranspiration of the crop by PenmanMonteith FAO standard (PEREIRA et al., 2015). The climatic water balance evidenced an average annual water deficit of $200 \mathrm{~mm}$ in the region, concentrated between the months of June to October. When looking at the averages in 2011, 2012, it was noted that the deficit in October got close to $180 \mathrm{~mm}$ in 2011 and $250 \mathrm{~mm}$ in 2012 (Figure 1).

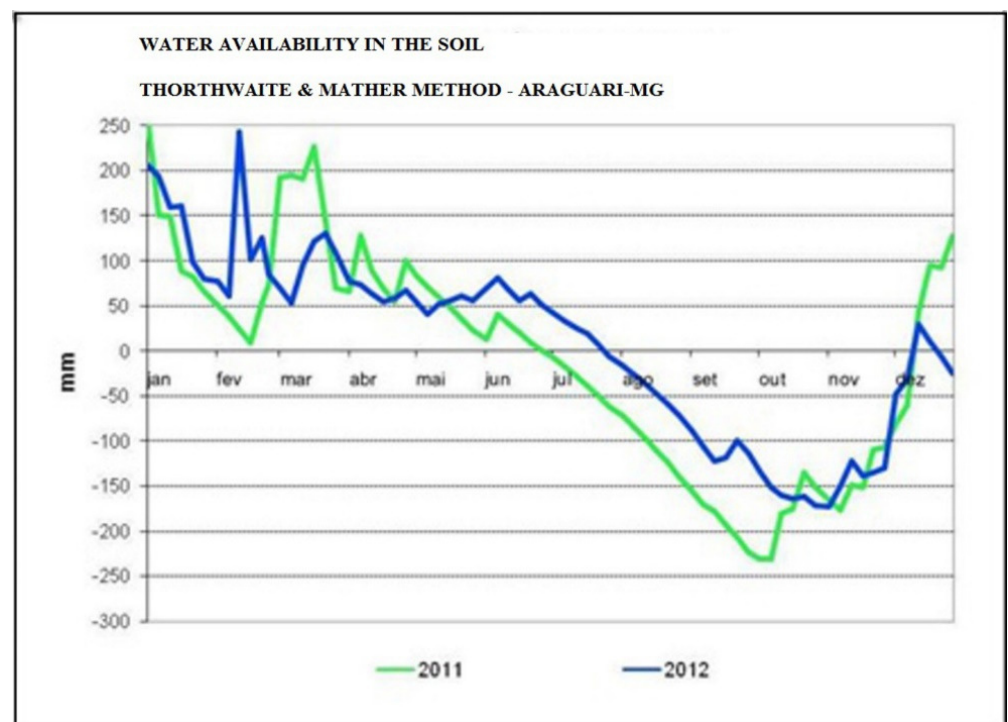

Figure 1. Extract of normal water balance in the region of Araguari, MG. (MAPA-PROCAFÉ, 2015).

Used coffee cultivate Mundo Novo variety IAC 379-19, established in 2002. Each plot consisted of 10 plants distributed in five lines with spacing of $4 \mathrm{~m}$ between the same and $0.8 \mathrm{~m}$ between plants. The useful area consisted of six central plants, totaling $19.2 \mathrm{~m} 2$ per plot.

The experimental design was a randomized complete block design with two factors and three replications. The first factor was product dose $(0.25$ $\mathrm{L} \mathrm{ha}^{-1}$ and $0.5 \mathrm{~L} \mathrm{ha}^{-1}$ per application) and the second factor was the period of applications according to the phenological stages (pre-flowering, postflowering and pinhead). The control treatment (control) did not undergo the application of the bioregulators (Table 1).

The product used was the Biozyme TF®, which consists of a foliar fertilizer with action of growth regulator of plant, consisting of: total nitrogen $(\mathrm{N}) 1.73 \% \mathrm{w} / \mathrm{w}$, water-soluble potassium oxide $\left(\mathrm{K}_{2} \mathrm{O}\right) 5.00 \% \mathrm{w} / \mathrm{w}$, total organic carbon 3.50 $\% \mathrm{w} / \mathrm{w}$, water soluble boron content (B) $0.08 \%$ w/w, water-soluble iron content $(\mathrm{Fe}) 0.49 \%$ w/w, water soluble manganese content (Mn) $1.00 \% \mathrm{w} / \mathrm{w}$, water soluble zinc content (Zn) $2.43 \%$ w/w, water soluble sulfur (S) $2.10 \% \mathrm{w} / \mathrm{w}$, phytohormones: gibberellin $32.2 \mathrm{mg} \mathrm{dm}^{-3}$, indole acetic acid (auxin) $32.2 \mathrm{mg} \mathrm{dm}^{-3}$ and zeatin (cytokinin) $83.2 \mathrm{mg} \mathrm{dm}^{-3}$.

The plant management, nutritional, and harvesting were carried out in accordance with recommendation of MAPA-Procafé (2015). The dressing was applied via fertirrigation with $100 \mathrm{~kg}$ of $\mathrm{N}, 175 \mathrm{~kg}$ of $\mathrm{P}$ and $400 \mathrm{~kg}$ of $\mathrm{K}$ of formulated 5 20-20 (2 $\left.\mathrm{tha}^{-1}\right)$ in four applications in the months of September, November, January and March of analyzed agricultural years.

The plant growth regulator applications were performed at the time of pre-flowering in September 11, 2010, post-flowering on October 9, 2010 and pinhead phase on October 29, 2010. In the second year, the applications were made at the same phases on September 2, 2011, October 1 and November 1 2011, respectively. 
Table 1. Doses and plant growth regulator application period in drip irrigated coffee plantation

\begin{tabular}{lll}
\hline Treatments & $\begin{array}{l}\text { Doses of bioregulators } \\
\mathrm{ha}^{-1} \text { ) }\end{array}$ & Application time \\
\hline Control & 0 & ---------------- \\
2 & 0.25 & Pre-flowering, post-flowering and pinhead \\
3 & 0.25 & Pre-flowering and post-flowering \\
4 & 0.25 & Post-flowering and pinhead \\
5 & 0.50 & Pre-flowering \\
6 & 0.50 & Post-flowering \\
7 & 0.50 & Pinhead \\
8 & 0.50 & Pre-flowering and post-flowering \\
9 & 0.50 & Post-flowering and pinhead \\
10 & 0.50 & Pre-flowering, post-flowering and pinhead \\
\hline
\end{tabular}

Four evaluations of biometric aspects were conducted (number of internodes and length of reproductive branches in centimeters) during two evaluated agricultural years. They were performed in the following periods: November 2010, May and September 2011, and April 2012, coinciding with the times of expansion of fruits, ripening of fruits, pre and post flowering and fruit maturation, respectively (MAPA-PROCAFÉ, 2015).

The reproductive branches were randomly selected from the two sides of the plant. They were measured with the aid of a tape and the formed internodes were counted from the last productive node in the previous harvest. Later the data were noted in a field spreadsheet and the average for each repetition was calculated.

In May 2011 and April 2012, during fruit maturation time, the fruits from the 4th and 5th node of reproductive branches were included and the average for each period was calculated.

Biometric evaluations were performed in order to promote a comparison between the formation of the new internodes and the size of the reproductive branches in the plant, helping to estimate the application efficiency of bioregulators for the next harvest, and check if the use of plant growth regulator promoted any increase of production.

Manual harvest and drying were performed in June 2011 and June 2012. The fruits were collected from the ground and plants. Later, the fruits were separated into bags, which were weighed and a sample of $1 \mathrm{~kg}$ was taken. The hulls and impurities were removed and the sample was weighed to calculate the yield.

The results were analyzed using analysis of variance and Tukey test, at 0.05 of significance with the MSSA Agri software (CANTERI et al., 2001).

\section{RESULTS AND DISCUSSION}

The growth evaluation, length of reproductive branches (LRB) and number of nodes $(\mathrm{NN})$, are presented in Table 2. In November 2010, there was no difference among the treatments regarding the number of internodes comparing with the control.

There was a decrease in length of reproductive branches in the treatments with the use of the plant growth regulator at $0.5 \mathrm{~L} \mathrm{ha}^{-1}$ during pre-flowering and post-flowering, post-flowering and pinhead, and pre-flowering, post-flowering and pinhead comparing with the control only for the first year of application of the product, 2010. (Table 2), as authors such as Silva et al. (2010) found that those treated with plant growth regulators function as activators of the metabolism of the cell, giving force to the immune system, reactivating physiological processes at different stages of development, stimulating root growth, inducing the formation of new shoots.

In November 2010, the treatments with the use the growth regulator differ from one another in the length of reproductive branches at doses of 0.25 $\mathrm{L} \mathrm{ha}^{-1}$ and $0.05 \mathrm{~L} \mathrm{ha}^{-1}$, with applications in two periods (pre-flowering and post-flowering and postflowering and pinhead) and three periods (preflowering, post- flowering and pinhead, respectively (Table 2).

In May 2011, the number of internodes in all treatments differed in relation to control $(\mathrm{p}>$ $0,05)$, but the treatments did not differ between one another. There was a higher average growth in length of reproductive branches with plant growth regulator treatments at a dose of $0.25 \mathrm{~L} \mathrm{ha}^{-1}$ when applied at one period (pre-flowering), two periods (post-flowering and pinhead) and three periods (preflowering, post-flowering and pinhead); at a dose of 
$0.5 \mathrm{~L} \mathrm{ha}^{-1}$ when applied at one period (pre-flowering and pinhead), two periods (pre-flowering and postflowering, post flowering and pinhead) and three periods (pre-flowering, post-flowering and pinhead) comparing to control ( $\mathrm{p}>0.05)$ (Table 2).

Table 2. Number of nodes (N.N.) and length of reproductive branches (L.R.B.) in coffee submitted to the application of plant growth regulators in different doses and development times, after two years of applications.

\begin{tabular}{|c|c|c|c|c|c|c|c|c|}
\hline \multirow[b]{2}{*}{ Treatments } & \multicolumn{2}{|c|}{ November 2010} & \multicolumn{2}{|c|}{ May 2011} & \multicolumn{2}{|c|}{ October 2011} & \multicolumn{2}{|c|}{ April 2012} \\
\hline & N.N. & $\begin{array}{l}\text { L.R.B } \\
(\mathrm{cm})\end{array}$ & N.N. & $\begin{array}{l}\text { L.R.B } \\
(\mathrm{cm})\end{array}$ & N.N & $\begin{array}{l}\text { L.R.B } \\
(\mathrm{cm})\end{array}$ & N.N. & $\begin{array}{l}\text { L.R.B } \\
(\mathrm{cm})\end{array}$ \\
\hline Control & $6 a$ & $14.2 \mathrm{a}$ & $8 \mathrm{~b}$ & $13.0 \mathrm{~b}$ & $4 \mathrm{~b}$ & $6.6 \mathrm{c}$ & $7 \mathrm{bc}$ & $21.7 \mathrm{a}$ \\
\hline $\begin{array}{l}\text { Bioregulator at } 0.25 \mathrm{~L} \mathrm{ha} \\
\text { (Pre and post-flowering } \\
\text { pinhead) }\end{array}$ & $g, 6 a$ & $13.7 \mathrm{a}$ & $11 \mathrm{a}$ & $20.5 \mathrm{a}$ & $6 \mathrm{a}$ & $18.7 \mathrm{ab}$ & $8 a b c$ & $24.2 \mathrm{a}$ \\
\hline $\begin{array}{l}\text { Bioregulator at } 0.25 \mathrm{~L} \mathrm{ha} \\
\text { (Pre and post-flowering) }\end{array}$ & ${ }^{-1} 6 \mathrm{a}$ & $13.5 \mathrm{a}$ & $10 \mathrm{a}$ & $17.7 \mathrm{ab}$ & $6 \mathrm{a}$ & $17.7 \mathrm{ab}$ & $6 \mathrm{c}$ & $22.1 \mathrm{a}$ \\
\hline $\begin{array}{l}\text { Bioregulator at } 0.25 \mathrm{~L} \mathrm{ha} \\
\text { (Post-flowering } \\
\text { pinhead) }\end{array}$ & d $6 a$ & $13.3 \mathrm{a}$ & $10 \mathrm{a}$ & $18.9 \mathrm{a}$ & $6 \mathrm{a}$ & $15.6 \mathrm{~b}$ & $7 \mathrm{bc}$ & $21.9 \mathrm{a}$ \\
\hline $\begin{array}{l}\text { Bioregulator at } 0.5 \mathrm{~L} \mathrm{ha}^{-} \\
\text {(Pre-flowering) }\end{array}$ & ${ }^{-1} 6 \mathrm{a}$ & $12.6 \mathrm{ab}$ & $10 \mathrm{a}$ & $20.0 \mathrm{a}$ & $6 \mathrm{a}$ & $19.9 \mathrm{a}$ & $8 a b c$ & $21.9 \mathrm{a}$ \\
\hline $\begin{array}{l}\text { Bioregulator at } 0.5 \mathrm{~L} \mathrm{ha} \\
\text { (Post-flowering) }\end{array}$ & ${ }^{-1} 6 \mathrm{a}$ & $12.4 \mathrm{ab}$ & $10 \mathrm{a}$ & $17.8 \mathrm{ab}$ & $6 \mathrm{a}$ & $17.3 \mathrm{ab}$ & $6 c$ & $20.6 \mathrm{a}$ \\
\hline $\begin{array}{l}\text { Bioregulator at } 0.5 \mathrm{~L} \text { ha } \\
\text { (Pinhead) }\end{array}$ & ${ }^{-1} 6 \mathrm{a}$ & $12.3 \mathrm{ab}$ & $10 \mathrm{a}$ & $22.1 \mathrm{a}$ & $6 \mathrm{a}$ & $19.5 a b$ & $8 a b c$ & $24.3 \mathrm{a}$ \\
\hline $\begin{array}{l}\text { Bioregulator at } 0.5 \mathrm{~L} \text { ha } \\
\text { (Pre and post-flowering) }\end{array}$ & ${ }^{-1} 6 \mathrm{a}$ & $11.2 \mathrm{~b}$ & $10 \mathrm{a}$ & $20.1 \mathrm{a}$ & $6 \mathrm{a}$ & $17.9 \mathrm{ab}$ & $9 a b$ & $27.7 \mathrm{a}$ \\
\hline $\begin{array}{ll}\text { Bioregulator at } & 0.5 \mathrm{~L} \\
\text { (Post-flowering } & \\
\text { pinhead) } & \text { anc } \\
& \end{array}$ & d $6 \mathrm{a}$ & $11.2 \mathrm{~b}$ & $10 \mathrm{a}$ & $20.1 \mathrm{a}$ & $6 \mathrm{a}$ & $19.5 \mathrm{ab}$ & $10 \mathrm{a}$ & $22.6 \mathrm{a}$ \\
\hline $\begin{array}{l}\text { Bioregulator to } 0.5 \mathrm{~L} \mathrm{ha} \\
\text { (Pre and post-flowering } \\
\text { pinhead) }\end{array}$ & $\mathrm{g}, 7 \mathrm{a}$ & $11.1 \mathrm{~b}$ & $10 \mathrm{a}$ & $20.6 \mathrm{a}$ & $6 \mathrm{a}$ & $20.6 \mathrm{a}$ & $10 \mathrm{a}$ & $26.3 \mathrm{a}$ \\
\hline C.V. (\%) & 7.60 & 5.40 & 5.27 & 9.36 & 4.63 & 7.94 & 7.52 & 10.46 \\
\hline
\end{tabular}

Means followed by the same letter in the column do not differ by Tukey test at $5 \%$ error significance.

In October 2011, the length of reproductive branches for treatments with the use of bioregulators grew more comparing with the control, producing a greater number of nodes. There was higher growth in reproductive branches for treatments that used the bioregulator in doses of $0.25 \mathrm{~L} \mathrm{ha}^{-1}$ when applied in two periods (post-flowering and pinhead) and the dose of $0.5 \mathrm{~L} \mathrm{ha}^{-1}$ when applied once (pre-flowering and in pinhead), twice (pre-flowering and postflowering, post-flowering and pinhead) and three times (pre-flowering and post-flowering, and pinhead) (Table 2).

For the length of the branches plagiotrópicos noted that among the treatments with the use of bioregulator, in October 2011, only the dose of $0.25 \mathrm{~L} \mathrm{ha}^{-1}$ applied in two seasons (postflowering and pinhead) differ from the best treatments with the dose of $0.5 \mathrm{~L} \mathrm{ha}^{-1}$ applied at a time (pre-flowering) and in three periods (pre and post-flowering, and pinhead) ( $\mathrm{p}>0.05)$ (Table 2).

In April 2012 (Table 2), using the dose of $0.5 \mathrm{~L} \mathrm{ha}^{-1}$ applied in two periods (post-flowering and pinhead) and three periods (pre-flowering, postflowering, and pinhead) there was an increase in the production of internodes comparing with the control ( $p>0,05)$. Analyzing the treatments at the dose of $0.25 \mathrm{~L} \mathrm{ha}^{-1}$ applied twice a year (pre-flowering and post flowering, post-flowering and pinhead) and 0.5 $\mathrm{L} \mathrm{ha}^{-1}$ applied only in the period of pinhead, produced less internodes than two better treatments - dose of $0.5 \mathrm{~L} \mathrm{ha}^{-1}$ applied in two periods (postflowering and pinhead) and three periods (preflowering, post-flowering, and pinhead). The length of internodes did not differ between the treatments and control. 
By analyzing the number of internodes and the length of reproductive branches, it was found that there was no relation between them, as shown in the April 2012 evaluation, where $0.5 \mathrm{~L} \mathrm{ha}^{-1}$ dose applied twice a year (post-flowering and pinhead) averaged 10 nodes, and the average length of reproductive branches was $22.6 \mathrm{~cm}$. Although the treatment using the same dose, but applied at three times (before and after flowering and pinhead) promoted the same average of 10 nodes and the average length of $26.3 \mathrm{~cm}$. The increase observed in the evaluation times for the number of nodes is of great importance for agricultural production of coffee as it guarantees increased productivity in the following year (Table 2).

The bioregulator used in the study has in its composition synthetic substance with action similar to that of major natural phytohormones, cytokinin, auxin and gibberellin. They activate genes responsible for the development of the plant length, and may well explain the increase in the number of internodes, in the length of branches and in productivity using a dose of $0.5 \mathrm{~L} \mathrm{ha}^{-1}$ of bioregulators (Table 2).

According Costa et al. (2010) the bioregulator promoted greater vegetative growth in the number of we developed in reproductive branches, primordial to ensure the productivity of the subsequent year, dependent on these us, in which are located the fruit, as well as the sheets considered source that fill the fruit.

It was observed that for the first evaluated crop year (2010/2011) treatments with the dose of $0.25 \mathrm{~L} \mathrm{ha}^{-1}$ applied in two periods (pre-flowering and post-flowering, post-flowering and pinhead) and treatments with the dose of $0.5 \mathrm{~L} \mathrm{ha}^{-1}$ applied at one period (pre-flowering; pinhead), two periods (preflowering and post-flowering, post-flowering and pinhead) and three periods (pre-flowering, postflowering, and pinhead) differed from the control in relation to average biometric variable of fruits from the fourth and fifth node (Table 3).

Table 3. The average of fruits from the 4th and 5th node of reproductive branches of the coffee submitted to the application of plant growth regulators in different doses and application times, after two growing periods, Araguari-MG

\begin{tabular}{|c|c|c|}
\hline Treatments & Crop 2010/2011 & Crop 2011/2010 \\
\hline Control & $4 \mathrm{~b}$ & $4 \mathrm{~b}$ \\
\hline $\begin{array}{l}\text { Bioregulator to } 0.25 \mathrm{~L} \mathrm{ha}^{-1} \text { (Pre and post-flowering, } \\
\text { pinhead) }\end{array}$ & $10 \mathrm{ab}$ & $13 \mathrm{a}$ \\
\hline Bioregulator to $0.25 \mathrm{~L} \mathrm{ha}^{-1}$ (Pre and post-flowering) & $13 \mathrm{a}$ & $13 \mathrm{a}$ \\
\hline Bioregulator to $0.25 \mathrm{~L} \mathrm{ha}^{-1}$ (Post-flowering and pinhead) & $12 \mathrm{a}$ & $10 \mathrm{ab}$ \\
\hline Bioregulator to $0.5 \mathrm{~L} \mathrm{ha}^{-1}$ (Pre-flowering) & $13 \mathrm{a}$ & $12 \mathrm{a}$ \\
\hline Bioregulator to $0.5 \mathrm{~L} \mathrm{ha}^{-1}$ (Post-flowering) & $11 \mathrm{ab}$ & $13 \mathrm{a}$ \\
\hline Bioregulator to $0.5 \mathrm{~L} \mathrm{ha}^{-1}$ (Pinhead) & $13 \mathrm{a}$ & $14 \mathrm{a}$ \\
\hline Bioregulator to $0.5 \mathrm{~L} \mathrm{ha}^{-1}$ (Pre and post-flowering) & $13 \mathrm{a}$ & $10 \mathrm{ab}$ \\
\hline Bioregulator to $0.5 \mathrm{~L} \mathrm{ha}^{-1}$ (Post-flowering and pinhead) & $15 \mathrm{a}$ & $13 \mathrm{a}$ \\
\hline Bioregulator to $0.5 \mathrm{~L} \mathrm{ha}^{-1}$ (Pre and post-flowering, pinhead) & $14 \mathrm{a}$ & $15 \mathrm{a}$ \\
\hline C.V. $(\%)$ & 19.44 & 12.66 \\
\hline
\end{tabular}

Means followed by the same letter in the column do not differ by Tukey test at $5 \%$ probability.

In the second year (2011/2012), the use of bioregulator at a dose of $0.25 \mathrm{~L} \mathrm{ha}^{-1}$ applied at two periods (pre-flowering and post-flowering) and three periods (pre-flowering, post-flowering, and pinhead) and the dose of $0.5 \mathrm{~L} \mathrm{ha}^{-1}$ applied in one period (pre-flowering, post-flowering and pinhead) in two periods (post-flowering and pinhead) and three periods (pre-flowering, post flowering, and pinhead), differed from the control in the average number of fruits on the fourth and fifth node of reproductive branches (Table 3 ).

Costa et al. (2010) evaluating the implementation of bioregulators at three different periods, pre-flowering, 30 days after flower anthesis (R7) and 30 days after R7, at concentrations of 0.1 , 0.2 and $0.4 \%$ in solution, regarding the average of fruit set between the 4th and the 5th node of productive branches, affirmed that the application was decisive for the fruit set in different application 
times, demonstrating the effectiveness of the synergistic effect in reducing fruit abscission, by raising the concentration of phytohormone in these organs, thus promoting increased productivity. The bioregulators have synthetic substances similar to phytohormones, and this may be the most probable explanation for the increased number of fruits.
In the 2010/2011 period the dose of $0.25 \mathrm{~L}$ $\mathrm{ha}^{-1}$ and $0.5 \mathrm{~L} \mathrm{ha}^{-1}$ resulted in production equal to or greater than the control group, only the $0.5 \mathrm{~L} \mathrm{ha}^{-1}$ dose provided significant increment in productivity when applied pre-flowering and post-flowering. After the 2011/2012 harvest, there was no difference in any of the treatments when comparing with the control (Table 4).

Table 4. Coffee Productivity (bags ha ${ }^{-1}$ ) at different doses and periods of application of bioregulator, AraguariMG, crops 2010/2011 and 2011/2012

\begin{tabular}{|c|c|c|c|}
\hline Treatments & Crop 2010/2011 & Crop 2011/2012 & Average crops \\
\hline Control & $38.5 \mathrm{~b}$ & $46.1 \mathrm{a}$ & $42.3 \mathrm{~b}$ \\
\hline $\begin{array}{l}\text { Bioregulator to } 0.25 \mathrm{~L} \mathrm{ha}^{-1} \text { (Pre and } \\
\text { post-flowering, pinhead) }\end{array}$ & $48.4 \mathrm{ab}$ & $42.0 \mathrm{a}$ & $45.2 \mathrm{ab}$ \\
\hline $\begin{array}{l}\text { Bioregulator to } 0.25 \mathrm{~L} \mathrm{ha}^{-1} \text { (Pre and } \\
\text { post-flowering) }\end{array}$ & $42.9 \mathrm{ab}$ & 39.7 a & $41.3 \mathrm{~b}$ \\
\hline $\begin{array}{l}\text { Bioregulator to } 0.25 \text { L ha }{ }^{-1} \text { (Post- } \\
\text { flowering and pinhead) }\end{array}$ & $43.3 \mathrm{ab}$ & $43.5 \mathrm{a}$ & $43.4 \mathrm{ab}$ \\
\hline $\begin{array}{l}\text { Bioregulator to } 0.5 \quad \mathrm{~L} \quad \mathrm{ha}^{-1} \text { (Pre- } \\
\text { flowering) }\end{array}$ & $39.0 \mathrm{~b}$ & $46.2 \mathrm{a}$ & $42.6 \mathrm{~b}$ \\
\hline $\begin{array}{l}\text { Bioregulator to } 0.5 \quad \mathrm{~L} \quad \mathrm{ha}^{-1} \text { (Post- } \\
\text { flowering) }\end{array}$ & $44.0 \mathrm{ab}$ & $54.0 \mathrm{a}$ & $49.0 \mathrm{ab}$ \\
\hline Bioregulator to $0.5 \mathrm{~L} \mathrm{ha}^{-1}$ (Pinhead) & $45.6 \mathrm{ab}$ & $50.4 \mathrm{a}$ & $48.0 \mathrm{ab}$ \\
\hline $\begin{array}{l}\text { Bioregulator to } 0.5 \mathrm{~L} \mathrm{ha}^{-1} \text { (Pre and post- } \\
\text { flowering) }\end{array}$ & $56.5 \mathrm{a}$ & 59.9 a & $58.2 \mathrm{a}$ \\
\hline $\begin{array}{l}\text { Bioregulator to } 0.5 \text { L ha }{ }^{-1} \text { (Post- } \\
\text { flowering and pinhead) }\end{array}$ & $47.2 \mathrm{ab}$ & $62.5 \mathrm{a}$ & $54.8 \mathrm{ab}$ \\
\hline $\begin{array}{l}\text { Bioregulator to } 0.5 \mathrm{~L} \mathrm{ha}^{-1} \text { (Pre and post- } \\
\text { flowering, pinhead) }\end{array}$ & $44.7 \mathrm{ab}$ & $55.8 \mathrm{a}$ & $50.3 \mathrm{ab}$ \\
\hline C.V. $(\%)$ & $11.33 \%$ & $20.27 \%$ & $16.95 \%$ \\
\hline
\end{tabular}

Means followed by the same letter in the column do not differ by Tukey test at $5 \%$ probability.

Studies with other cultures demonstrated the importance of using plant growth regulator in agriculture in relation to productivity. Bertolin et al. (2010) found in soybean culture, that when using the bioregulator applied on the leaves or seeds there was an average increase of $37 \%$ in productivity comparing with the control. Other authors such as Vieira \& Santos (2005) presented average increments of $24.3 \%$ in productivity of soybeans.

In this experiment, it was noted that using a dose of $0.5 \mathrm{~L} \mathrm{ha}^{-1}$ per application caused increments ranging from $0.5 \%$ to $46.9 \%$ over the control. The best increments were when the bioregulator was applied in two doses of $0.5 \mathrm{~L} \mathrm{ha}^{-1}$ per application. The dose of $0.25 \mathrm{~L} \mathrm{ha}^{-1}$ per application did not differ in relation to the control, with a productivity of almost $14 \%$ less than the control.

Analysis showed that the total applied dose did not interfere in production, but the amount used in each application, even in treatments with $0.25 \mathrm{~L}$ $\mathrm{ha}^{-1}$ per application totaling $0.75 \mathrm{~L} \mathrm{ha}^{-1}$, did not obtained results equal to or greater than the control. However, the $0.5 \mathrm{~L} \mathrm{ha}^{-1}$ application produced higher results than the control but only in one application in the 2011/2012 crop. These differences in productivity indicate that in Brazil some agricultural crops have already reached high levels of technology, achieving high productivity, and are not constrained by limitations of nutrition or water, leading to the use of bioregulators that may be rewarding as well as economic (CASTRO et al., 2009).

Being a biennial crop, it was necessary to average yields from two harvests, however it did not provide differences in production comparing with the control. But, there were increments of up to $38 \%$ of the average yield at the dose of $0.5 \mathrm{~L} \mathrm{ha}^{-1}$.

By analyzing all variables together, the number of internódios, the length of reproductive branches, the average number of fruits on the 4th and 5th internode and productivity (Table 2, 3 and 4), it was not possible to demonstrate that the 
productivity this interconnected with the other variables, being necessary evaluate more agricultural years. Silva et al. (2008) found not be so simple to establish productivity comparisons between crops, as it depends on biennial changes, cultivar, plant density and climatic conditions which vary from year to year.

\section{CONCLUSIONS}

The application of plant growth regulator at different growth stages of development of coffee leads to increased biometric variables of coffee: the number of internodes, the average of fruits on the 4th and 5th node and the length of reproductive branches.

The use of bioregulators increases productivity of coffee plants, especially at a dose of $0.5 \mathrm{~L} \mathrm{ha}^{-1}$ per application regardless of the application period, promoting increments of up to $46.9 \%$ in productivity.

It cannot be said that the presence of substances similar to phytohormones in plant growth regulators is responsible for the increase in productivity without making the application of these in isolation.

RESUMO: O objetivo do trabalho foi avaliar a eficácia do biorregulador aplicado em diferentes estádios fenológicos na cultura do café. O experimento foi conduzido nos anos agrícola de 2010/2011 e 2011/2012 na fazenda Docas 1, utilizando café cultivar Mundo Novo variedade IAC 379-19, com o espaçamento de $4 \mathrm{~m}$ entre linhas e $0,8 \mathrm{~m}$ entre plantas e 10 plantas por parcela. O delineamento experimental utilizado foi o de blocos casualizados, com dois fatores e três repetições, sendo o primeiro fator dose do produto $\left(0,25 \mathrm{~L} \mathrm{ha}^{-1}\right.$ e $0,5 \mathrm{~L} \mathrm{ha}^{-1}$ em cada aplicação) e o segundo a época de aplicações de acordo com os estádios fenológicos (pré-florada, pós-florada e chumbinho) e o tratamento controle (testemunha) que constou-se da ausência de aplicação do biorregulador. Realizou-se avaliações dos aspectos biométricos (número de internódios e comprimento de ramos plagiotrópicos em centímetro, contagem dos frutos do $4^{\circ}$ e $5^{\circ}$ nó dos ramos plagiotrópicos) e a produtividade, e realizou-se o teste de Tukey a 0,05 de significância. A aplicação do biorregulador em diferentes estádios fenológicos de desenvolvimento do cafeeiro promove um aumento nas variáveis biométricas do cafeeiro, número de internódios, a média de frutos do quarto e quinto nó e o comprimento dos ramos plagiotrópicos. A produtividade do cafeeiro pode ser incrementada com o uso de biorreguladores, principalmente na dose de $0,5 \mathrm{~L} \mathrm{ha}^{-1}$ por aplicação independente da época de aplicação, promovendo incrementos de até 46,9\% na produtividade. Não é possível afirmar que a presença de substâncias semelhantes aos fitohormônios nos biorreguladores é responsável pelo incremento na produtividade, sem realizar a aplicação dessas isoladamente.

PALAVRAS-CHAVE: Coffea arabica L. Fitohormônios. Tecnologia de fertilizantes.

\section{REFERENCES}

ALBRECHT, L. P.; BRACCINI, A. L.; ÁVILA, M. R.; BARBOSA, M. C.; RICCI, T. T.; ALBRECHT, A. J. P. Aplicação de biorregulador na produtividade do algodoeiro e qualidade de fibra. Scientia Agraria, Curitiba, v. 10, p. 191-198, 2009. http://dx.doi.org/10.5380/rsa.v10i3.14474

ÁVILA, M. R.; BRACCINI, A. L.; SCAPIM, C. A.; ALBRECHT, L. P.; TONIN, T. A.; STÜLP, M. Bioregulator application, agronomic efficiency, and quality of soybean seeds. Scientia Agricola, Piracicaba, v. 65, p. 567- 691, 2008. http://dx.doi.org/10.1590/s0103-90162008000600006

BERTOLIN, D. C; SÁ, M. C.; ARF, O.; JUNIOR, E. F.; COLOBOM, A. S.; CARVALHO; F. L. B. M. Aumento da produtividade de soja com a aplicação de bioestimulantes. Bragantia, Campinas, v. 69, n. 2, p. 339-347, 2010. http://dx.doi.org/10.1590/S0006-87052010000200011

BINSFELD, J. A.; BARBIERI, A. P. P.; HUTH, C.; CABRERA, I. C.; MERTZ, L. M. Uso de bioativador, bioestimulante e complexo de nutrientes em sementes de soja. Pesquisa Agropecuária Tropical, Goiânia. v. 44, n. 1, 2014.

CAMPOS, M. F.; ONO, E. O.; BOARO, C. S. F.; RODRIGUES, J. D. Análise de crescimento em plantas de soja tratadas com substâncias reguladoras. Revista Biotemas, Florianópolis, v. 21, p. 53-63, 2008.

http://dx.doi.org/10.5007/2175-7925.2008v21n3p53 
CANTERI, M. G., ALTHAUS, R. A., VIRGENS FILHO, J. S., GIGLIOTI, E. A., GODOY, C. V. SASM-Agri. Sistema para análise e separação de médias em experimentos agrícolas pelos métodos Scott-Knott, Tukey e Duncan. Revista Brasileira de Agrocomputação, v. 1, n. 2, p. 18-24, 2001.

CASTRO, P. R. D. C.; PITELLI, A. M. D. C. M.; PERES, L. E. P.; ARAMAKI, P. H. Análise da atividade reguladora de crescimento vegetal de tiametoxam através de biotestes. Publicatio UEPG-Ciências Exatas e da Terra, Agrárias e Engenharias, v. 13, n. 03, 2009.

COSTA, N. R.; DOMINGUES, M. C. S.; RODRIGUES, J. D. Desempenho do cafeeiro Icatu vermelho sob ação de biorregulador aplicado em fases reprodutivas da cultura. Agrarian, Dourados, v. 2, n. 5, p. 13-130, 2010.

FERREIRA, L. A.; OLIVEIRA, J. A.; VON PINHO, E. V. R.; QUEIROZ, D. L. Bioestimulante e fertilizante associados ao tratamento de sementes de milho. Revista Brasileira de Sementes, Brasília, v. 29, n. 2, p. 80-89, 2007. http://dx.doi.org/10.1590/S0101-31222007000200011

KLAHOLD, C. A.; GUIMARÃES, V. F.; ECHER, M. M.; KLAHOLD, A.; CONTIERO, R. L.; BECKER, A. Resposta da soja (Glycine max (L.) Merrill) à ação de bioestimulante. Acta Scientiarum Agronomy, Maringá, v. 28, n. 2, p. 179-185, 2006.

MAPA - PROCAFÉ, Estações de avisos fitossanitários boletim de avisos nº 028 - Alto Paranaíba/Triângulo Mineiro. Disponível em:

http://fundacaoprocafe.com.br/sites/default/files/boletim/triangulo/Boletim\%20Dezembro\%202012.pdf. Acesso em: 10 de mar. 2015.

MUGNAI, S.; AZZARELLO, E.; PANDOLFI,C.; SALAMAGNE, S.; BRIAND, X.; MANCUSO, S. Enhancement of ammonium and potassium root influxes by the application of marine bioactive substances positively affects Vitis vinifera plant growth. Journal of Applied Phycology, Firenze, v. 20, p. 177-182, 2008. http://dx.doi.org/10.1007/s10811-007-9203-6

PEREIRA, L. S.; ALLEN, R. G.; SMITH, M.; RAES, D. Crop evapotranspiration estimation with FAO56: Past and future. Agricultural Water Management, v. 147, p. 4-20, 2015.

http://dx.doi.org/10.1016/j.agwat.2014.07.031

SILVA, L. C. F; MANIERO, M. A.; CASAGRANDE, J. C.; STOLF; R.; PIEDADE, S. M. S. Agricultura bioestimulada. Cultivar Grandes Culturas, Pelotas, v. 14, p. 34-35, 2012.

SILVA, M. A; CATO, S. C; COSTA, A. G. F. Produtividade e qualidade tecnológica da soqueira de cana-deaçúcar submetida à aplicação de biorregulador e fertilizantes líquidos. Ciência Rural, Santa Maria, v. 40, n. 4, p. 774-780, 2010. http://dx.doi.org/10.1590/S0103-84782010005000057

SILVA, C. A.; TEODORO, R. E. F.; MELO, B. Produtividade e rendimento do cafeeiro submetido a lâminas de irrigação. Pesquisa Agropecuária Brasileira, Brasília, v. 43, n. 3, p. 387-394, 2008.

http://dx.doi.org/10.1590/S0100-204X2008000300014

VIEIRA, E. L.; SANTOS, C. M. G. Efeito de bioestimulante no crescimento e desenvolvimento inicial de plantas de algodoeiro. Magistra, Cruz das Almas, v. 17, p. 1-8, 2005. 